\title{
MEMBACA BERIMBANG DALAM MENINGKATKAN MINAT MEMBACA SISWA SEKOLAH DASAR DI KOTA MEDAN
}

\author{
Arnita $^{1 *}$, Rosmaini', Yulita Molliq ${ }^{2}$ \\ ${ }^{1}$ Jurusan Bahasa dan Sastra Indonesia, Fakultas Bahasa dan Seni, Universitas Negeri Medan, \\ Medan, Indonesia \\ ${ }^{2}$ Jurusan Matematika, Fakultas Matematika dan Ilmu Pengerahuan Alam, Universitas Negeri Medan, \\ Medan, Indonesia \\ * Penulis Korespondensi : arnita22@yahoo.com
}

\begin{abstract}
Abstrak
Hampir 90\% siswa kelas rendah terutama kelas satu dan dua di SDN 066055 belum mampu membaca dengan baik dan lebih dari 50\% siswa kelas tiga belum paham dengan apa yang dibacanya. Sementara kemampuan membaca siswa di SD IT Ulul Ilmi lebih baik dibanding SDN 066055, hampir 90\% siswa kelas satu dan duanya mampu membaca dan lebih dari 50\% siswa kelas tiganya paham dengan apa yang dibacanya. Namun strategi guru dalam mengajarkan membaca pada kedua sekolah tersebut masih konvensional. Dimana guru masih mengajarkan membaca dengan cara mengeja, abjad, suku kata tanpa ada variasi. Kemampuan anak juga berbeda-beda, ada anak yang mampu membaca tapi tidak paham dengan apa yang dibacanya. Bahkan ada anak yang belum mampu membaca dalam makna yang sebenarnya. Perbedaan kemampuan anak ini mengakibatkan perlunya pendekatan yang berbeda pula. Minimnya pengetahuan guru tentang teknik pengajaran membaca mengakibatkan banyak anak hanya mampu membaca dalam artian hanya mengeluarkan bunyi saja. Hal tersebut disebabkan sedikitnya guru yang mempunyai pengalaman dalam pelatihan-pelatihan yang berkaitan dengan inovasi pembelajaran khusunya pembelajaran membaca pada kelas rendah sekolah dasar. Oleh karena itu perlu dilakukan inovasi untuk meningkatkan minat membaca anak, sehingga dapat menumbuhkan sikap positif anak dalam belajar khususnya membaca, dengan mengadakan kegiatan membaca berimbang pada guru-guru SD di kota Medan.
\end{abstract}

Kata Kunci: Membaca berimbang, Minat membaca, Sekolah Dasar

\begin{abstract}
Nearly $90 \%$ of low grade students, especially first and second grade in SDN 066055 have not been able to read well and more than $50 \%$ of third graders have not understood what they read. While students' reading ability in SD Ulul Ilmi is better than SDN 066055, almost $90 \%$ of first and second graders are able to read and more than $50 \%$ of third graders are familiar with what they read. But the teacher's strategy in teaching reading on both schools is still conventional. Where teachers still teach reading by spelling, alphabet, syllables without any variation. The ability of children is also different, there are children who are able to read but do not understand what he read. There are even children who have not been able to read in the true meaning. Differences in the ability of these children lead to the need for different approaches. The lack of knowledge of teachers about reading teaching techniques resulted in many children only able to read in the sense that only the sounds. This is due to the lack of teachers who have experience in trainings related to learning innovation, especially reading learning in low grade elementary school. Therefore it is necessary to innovate to increase interest in reading children, so that it can grow a positive attitude of children in learning especially reading, by holding a balanced reading activity in elementary school teachers in the city of Medan.
\end{abstract}

Keywords: Reading balance, reading interest, elementary school

\section{PENDAHULUAN}

Membaca merupakan salah satu kegiatan penting dalam kehidupan masyarakat modern. Dengan membaca akan diperoleh berbagai informasi baru. Salah satu keterampilan dari empat keterampilan berbahasa yang diajarkan di sekolah adalah membaca. Mampu membaca bukan jaminan bahwa sesesorang akan memiliki keterampilan membaca yang baik. Namun terampil membaca tidak mungkin jika tidak memiliki kemampuan membaca. Tanpa memiliki kemampuan membaca yang memadai sejak dini, maka akan menjadi hambatan bagi siswa untuk bisa belajar dengan baik. Kemampuan membaca menjadi dasar utama tidak saja bagi pelajaran bahasa 
itu sendiri, tapi juga bagi pelajaran lainnya. Dengan membaca, siswa akan memperoleh pengetahuan yang sangat bermanfaat bagi pertumbuhan dan perkembangan daya nalar, sosial dan emosionalnya.

Menurut Ester R Manurung, kenyataannya berdasarkan survey yang dilakukan pada tahun 20132014 pada 4800 siswa kelas 2 SD di 400 SD dan MI, kemampuan membaca sekaligus memahami apa yang dibaca siswa di Indonesia masih sangat rendah.Bahkan masih dijumpai anak-anak lulusan SD yang belum mampu membaca dengan baik. Kemampuan membaca adalah kemampuan untuk mengucapkan kata-kata dari tulisan dan memahami arti kata-kata tersebut sebagaimana yang dimaksud oleh penulisnya. Kemampuan membaca harus dipelajari melalui serangkaian proses yang cukup panjang. Modal supaya seseorang bisa memahami bacaan dengan baik adalah memiliki intelegensi dalam taraf normal, penguasaan kosakata yang banyak, sikap positif terhadap kegiatan membaca, serta berminat untuk membaca (Ratna Wulan). Agar kemampuan membaca meningkat, jalan yang harus ditempuh adalah dengan meningkatkan jumlah pengusaaan kosakata, mengubah sikap terhadap membaca menjadi lebih positif, dan meningkatkan minat baca.

Salah satu hal penting yang memegang peranan dalam keberhasilan siswa dalam membaca adalah guru. Strategi yang harus dikelola dan diterapkan oleh guru saat pengajaran di kelas harus lebih variatif, sehingga siswa tidak jenuh mengikuti pembelajaran. Strategi ini menunjukkan peran penting dari seorang guru untuk mencapai tujuan pembelajaran. Secara umum, ada dua tanggung jawab yang mendasar dari seorang guru dalam mengajar bahasa di kelas yaitu untuk menyediakan lingkungan belajar bahasa yang kaya dan mendukung siswa dalam penggunaan bahasa.

Saat ini kita disuguhi fakta bahwa minat baca masyarakat Indonesia sangat rendah dibanding negara ASEAN lainnya. Berdasarkan data UNESCO tahun 2012, bahwa minat baca masyarakat Indonesia sebesar 0,001. Artinya, rata-rata secara nasional tak sampai satu judul buku yang dibaca oleh satu orang pertahunnya. Hal yang sangat berbeda terjadi dengan masyarakat Malaysia. Masyarakat malaysia mampu membaca 3 judul buku perorang pertahunnya. Begitu juga dengan Jepang, meraka mampu membaca 10 judul buku perorang pertahunnya (Aditya adiaksa).

Berdasarkan penelitian Ratna Wulan, perlakuan membaca secara bersama-sama memberi pengaruh terhadap peningkatan kemampuan membaca siswa SD di Yogyakarta. Penelitian ini dilakukan dengan membandingkan kemampuan membaca pada kelompok siswa yang diberi perlakuan dan kelompok siswa yang tidak diberi perlakuan. Dari penelitiannya diketahui bahwa aspek kognitif (penguasaan kosakata dan intelegensi) berperan langsung terhadap kemampuan membaca. Namun, tanpa adanya dukungan aspek afektif (sikap terhadap membaca dan minat membaca), kemampuan membaca tidak akan terwujud secara maksimal.

Ada banyak metode membaca yang dapat diterapkan pada siswa SD, diantaranya membaca berimbang dengan strategi membaca Bersama, Membaca Terbimbing, dan Membaca Mandiri. Strategi Membaca Bersama, Membaca Terbimbing, dan Membaca Mandiri memecahkan problema di atas dengan tujuan akhir untuk meningkatkan keterampilan anak dalam membaca dan memahami isi buku yang dibacanya. Ketiga strategi tersebut dikembangkan dalam empat keterampilan, dan keterampilan tersebut adalah kemampuan memprediksi, mengenal kosakata dan tanda baca, kelancaran membaca yang termasuk di dalamnya berupa intonasi suara, pemahaman isi buku, dan merangkum (Muhsan Hudi, 2016).

Selama ini dalam pembelajaran, strategi guru dalam mengajarkan membaca masih konvensional. Dimana guru masih mengajarkan membaca dengan cara mengeja, abjad, suku kata tanpa ada variasi. Kemampuan anak juga berbeda-beda sehingga perlu pendekatan yang berbeda pula. Fakta yang terlihat, kecenderungan anak-anak masih mengikuti apa yang disampaikan oleh guru tanpa disertai pemahaman atas apa yang dibacanya. Minimnya pengetahuan guru tentang teknik pengajaran membaca mengakibatkan banyak anak hanya mampu membaca dalam artian hanya mengeluarkan bunyi saja. Minimnya pengetahuan guru ini disebabkan sedikitnya guru yang mempunyai pengalam dalam pelatihan-pelatihan yang berkaitan dengan inovasi pembelajaran khusunya pembelajaran membaca pada kelas rendah sekolah dasar. Kalaupun ada pelatihan yang diselenggarakan pemerintah, hanya beberapa guru saja yang bisa ikut serta mewakili sekolah dan keseringan guru tersebut tidak mensosialisasikan ilmu dan pengalaman yang diperoleh kepada guruguru lainnya sehingga pelatihan yang diikuti kurang bermanfaat dalam penerapannya.

Mitra yang akan dilibatkan dalam kegiatan ini adalah SDS Ulul Ilmi dan SDN 066055. Kedua sekolah tersebut berada di Kecamatan Medan Denai kota Medan. Jarak lokasi kedua mitra dari Universitas Negeri Medan lebih kurang $5 \mathrm{~km}$. Berdasarkan informasi yang didapat dari kepala sekolah dan guru kelas di SDN 066055, hampir 70\% siswa kelas satu dan dua di sekolah tersebut kemampuan membacanya rendah. Dan lebih dari $50 \%$ siswa kelas tiga keterampilan membaca khusunya membaca pemahaman juga masih rendah. Sekolah hanya mempunyai dua 12 guru sudah termasuk 5 guru honor, dengan rata-rata jumlah murid tiap kelas 40 orang. Lebih dari $50 \%$ guru dengan usia lebih dari 50 tahun. Beberapa guru pernah mendapat kesempatan untuk mengikuti kegiatan-kegiatan peningkatan kualitas pembelajaran. Namun, sosialisasi dan 
aplikasi pengetahuan ynag diperoleh tidak pernah dilakukan. Bahkan beberapa sumbangan baik media maupun buku jarang digunakan dalam proses pembelajaran di sekolah dengan alasan kurangnya pendampingan.

Sedangkan pada SDS Ulul Ilmi kurang dari 20\% siswa kelas rendahnya memiliki kemampuan dan keterampilan membaca yang masih rendah. Karena sekolah masih relatif baru, umumnya usia guru masih relatif muda. Pengalaman guru-guru dalam kegiatan peningkatan kualitas pembelajaran juga masih kurang. Berdasarkan wawancara pada kepala sekolah, guru-guru mereka belum pernah terlibat dalam kegiatan-kegiatan inovasi pembelajaran yang diadakan pemerintah maupun lembaga-lembaga tertentu. Meski secara umum, sekolah sudah menerapkan metode pembelajaran inovasi, namum dalam pembelajaran membaca metode konvensional yang masih digunakan.

Sebenarnya dalam pembelajaran perlu dilakukan inovasi untuk meningkatkan minat membaca anak, sehingga dapat menumbuhkan sikap positif anak dalam belajar khususnya membaca. Perlu juga dilakukan kegiatan-kegiatan yang dapat meningkatkan pemahaman dan keterampilan guru dalam melakukan inovasi pembelajaran. Sebagai bagian dari perguruan tinggi yang menghasilkan guru, maka perlu untuk lebih pro aktif melakukan kegiatan yang memberi manfaat positif bagi guru. Oleh karena itu perlu dilakukan program atau kegiatan membaca berimbang bagi guru-guru untuk menumbuhkan sikap membaca dan minat membaca pada siswa SD di kota Medan.

\section{METODE PELAKSANAAN}

Sebelum melakukan pelatihan keterampilan literasi pada guru, maka akan dilihat terlebih dahulu kondisi awal guru. Kemudianakan dipetakan berapa guru yang sudah menguasai model-model inovatif dalam pembelajaran membaca dan menulis. Selain itu juga akan dilihat kondisi awal kemampuan membaca dan menulis siswa dengan cara mengambil sampel siswa dan diukur kemampuan membaca dan menulisnyanya. Dengan mengetahui kondisi awal guru maupun siswa, harapannya dapat dilihat apakah program ini memberi pengaruh atau tidak terhadap kemampuan berliterasi yang pada akhirnya akan menjadikan sekolah menjadi lingkungan yang kondusif untuk memupuk budaya suka baca siswa.

Sebelum kegiatan membaca berimbang, guru-guru dilatih terlebih dahulu dalam pembuatan big book selama 4 hari. Kemudian pelatihan membaca berimbang serta merancang program membaca dan pengelolaan buku berjenjang selama 4 hari, dan diakhiri dengan persiapan dan praktik pembelajaran di kelas sebenarnya. Sehingga tahapan pelaksanaan kegiatan IbM ini akan dibagi menjadi tiga tahap besar yang akan dirinci sebagai berikut :

1. Membuat big book
2. Membaca berimbang

3. Persiapan dan praktik mengajar.

4. Pengelolaan buku bacaan berjenjang disekolah

5. Rencana Tindak Lanjut

Keberlanjutan kegiatan ini dirintis dengan adanya kegiatan RTL (rencana Tindak Lanjut) dimana guru dan sekolah diminta untuk membuat serangkaian rencana kegiatan yang dilakukan secara rutin dan dilakukan tiap minggu sebagai upaya pembiasaan membaca pada siswa. Kegiatan-kegiatan tersebut dapat berbentuk seperti :

1. Adanya pembiasaan program membaca berimbang secara rutin.

2. Adanya pojok baca di halaman /trotoar sekolah dan sudut baca di kelas agar siswa mudah mengakses buku.

3. Adanya kegiatan presentasi dari hasil bacaan untuk meningkatkan pemahaman membaca pada siswa.

\section{HASIL DAN PEMBAHASAN}

Sebelum melakukan kegiatan maka dilakukan pengukuran terhadap kondisi awal siswa, untuk mengetahui bagai mana kemampuan membaca. Pengukuran kemampuan membaca dilakukan menggunakan teknik lima jari, dengan memperhatikan kesalahan ejaan, tanda baca dan pemahaman isi bacaan. Jika terjadi lima kali kesalahan pada satu halaman maka siswa dianggap belum mampu membaca.

Beberapa siswa dari SDS Ulul Ilmi dan SDN 066055 , kemudian diminta untuk membaca beberapa buku sesuai dengan kemampuan membaca siswa tersebut. Dari 9 siswa yang dijadikan sampel dalam pengukuran ini di sekolah Ulul Ilmi, umumnya mereka hanya mampu membaca secara nyaring tapitidakmemahamiapa yang dibaca.

Sedangkan di sekolah SDN 066055 dari 7 siswa sampel yang diukur kemampuan membacanya, ratarata siswa kurang mampu membaca karena tidak dapat menyambung huruf menjadi kata dankalimat dengan baik.
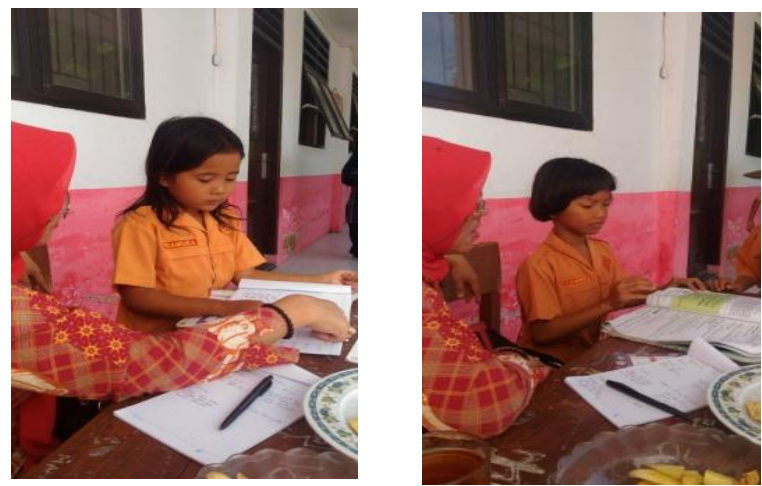

Gambar 1. Pengukuran kemampuan awal membaca pada siswa SDN 066055 
Selain melihat kondisi awal pada siswa, juga dilihat kondisi awal pada guru terhadap penguasaan modelmodel pembelajaran membaca dan penguasaan dalam mengembangkan media pembelajaran membaca. Dari 25 peserta yang hadir dalam kegiatan workshop kurang dari 5 orang guru pernah mendapatkan pengetahuan mengenai model-model pembelajaran inovatif namum tidak pernah mendapatkan pengetahun mengenai model pembelajarn membaca. Dan hanya 2 orang guru yang pernah mendapatkan pengetahuan mengenai mengembangkan media pembelajaran, dan tak satupun guru pernah mengembangkan media pembelajaran membaca.

Tahap awal kegiatan pembuatan peserta dibekali tentang tujuan dan manfaat penggunaan media Big Book sebagai media membaca permulaan pada siswa sekolah dasar. Anak-anak usia pendidikan dasar terutama kelas rendah seharusnya diisi oleh kegiatan belajar yang lebih interaktif dan menyenangkan, tetapi sayang dalam proses pembelajaran membaca di kelas rendah kebanyakan guru masih menggunakan media tradisional seperti buku paket saja. Biasanya guru mengajarkan cara membaca dengan mencontohkan cara membaca kata atau kalimat kemudian siswa mengulangi apa yang dibacakan oleh guru dari buku teks. Dalam proses pembelajaran seperti ini biasanya siswa duduk mendengarkan guru sambil memegang buku teks dan mengulang apa yang guru bacakan, begitu seterusnya. Oleh karena itu pada kegiatan ini guru dibekali bagaimana mengembangkan media pembelajaran membaca Big Book yang mampu mengakomodir kebutuhan siswa kelas rendah.

Penggunaan Big Book dalam pembelajaran bahasa memiliki beberapa tujuan, yaitu:

1. Memberi pengalaman membaca.

2. Membantu siswa memahami buku.

3. Mengenalkan berbagai jenis bahan bacaan kepada siswa.

4. Memberi peluang kepada guru memberi contoh bacaan yang baik.

5. Melibatkan siswa secara aktif dalam pembelajaran.

6. Menyediakan contoh teks yang baik untuk digunakan siswa.

7. Menggali (www.prioritaspendidikan.org)

Dengan ukurannya yang besar disertai gambar yang menarik, dalam proses pembelajaran bahasa, Big Book memiliki beberapa keuntungan, seperti:

1. Memberikan kesempatan kepada siswa untuk terlibat dalam kegiatan pembelajaran bahasa yang menyenangkan.

2. Memungkinkan siswa melihat tulisan yang sama ketika guru membaca tulisan yang ada dalam Big Book.

3. Memungkinkan siswa secara bersama-sama memberi makna pada setiap tulisan yang ada dalam Big Book.
4. Membantu siswa untuk memahami hubungan antara bahasa lisan dan tulisan.

5. Mengembangkan semua aspek bahasa

6. Dapat diselingi percakapan yang relevan mengenai isi cerita dalam Big Book bersama siswa sehingga terjadi proses belajar yang interaktif. Topik bacaan akan berkembang sesuai dengan pengalaman dan imajinasi siswa. (Buku Sumber untuk Dosen LPTK, Draft Januari 2014: 44).
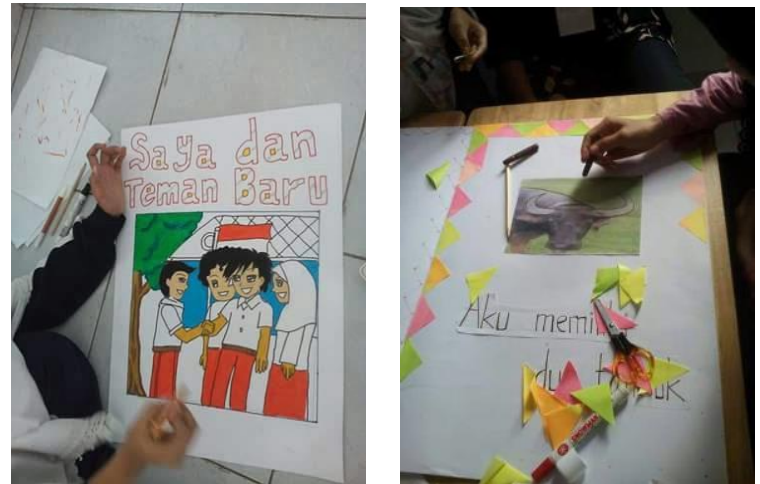

Gambar 2. Proses pembuatan Big Book

Setelah melakukan kegiatan pengembangan media pembelajaran big book, maka peserta mempfresentasukan hasil kerja pembuatan big book per kelompok dan mendengarkan masukan-masukan dari peserta lain dan fasilitor tentang big book yang sudah jadi. Agar dalam pembuatan big book berikutnya dapat membuat big book dengan lebih baik. Masukan-masuk yang yang umum diberikan berkaitan dengan gambit tokoh, penulisan kalimat, setting tempat, dan lain-lain.

Setelah sesi pembuatan big book, maka dilakukan refleksi bersama peserta. Refleksi memuat bagaimana perasaan peserta dalam pembuatan big book. Dari komentar peserta yang ditulis di kertas post it dan ditempelkan di plano, mereka mearasa bahawa kegiatan ini adalah hal yang baru, menyenangkan dan membuat mereka menjadi kreatif. Dan menjadi motivasi bagi peserta untuk membuat big book dengan tema yang berbeda.

Dalam kegiatan membaca bersama peserta dikenalkan apa itu membaca bersama sambil menonton video. Setelah itu peserta mendiskusikan apa yang ditonton dan seperti apa membaca bersama, memberikan masukan dan tanggapan terhadap membaca bersama. Dalam tahap aplikasi peserta mensimulasikan membaca bersama di kelompok masing-masing. Kemudian peserta yang mensmulasikan mendapat masukan dan saran dari peserta lain dan fasilitor . 

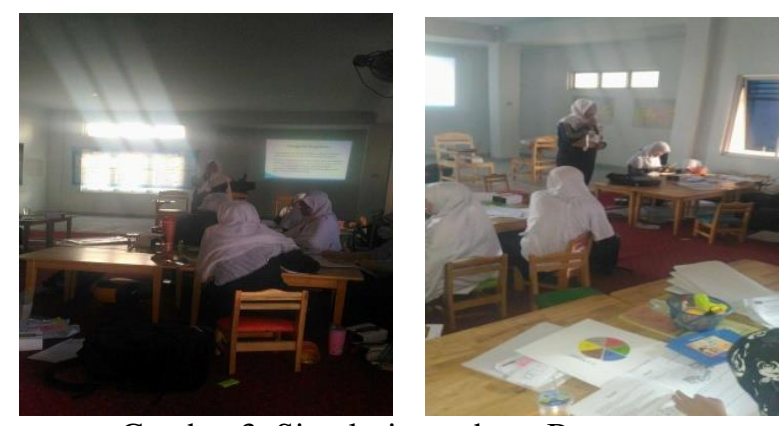

Gambar 3. Simulasi membaca Bersama

Dalam kegiatan membaca terbimbing peserta dikenalkan apa itu membaca terbimbing sambil menonton video. Setelah itu peserta mendiskusikan apa yang ditonton dan seperti apa membaca terbimbing, memberikan masukan dan tanggapam terhadap membaca terbimbing. Dalam tahap aplikasi peserta mensimulasikan membaca terbimbingdi kelompok masing-masing. Kemudian peserta yang mensmulasikan mendapat masukan dan saran dari peserta lain dan fasilitor .

Membaca mandiri diawali dengan diskusi pemahaman tentang membaca mandiri. Kemudian menonton video tentang contoh contoh kegiatan membaca mandiri. Setelah itu melakukan diskusi dan tanya jawab tentang kegiatan membaca mandiri di sekolah para peserta, satu atau dua orang menyampaikannya ke depan yang lain memberikan masukan atau saran.
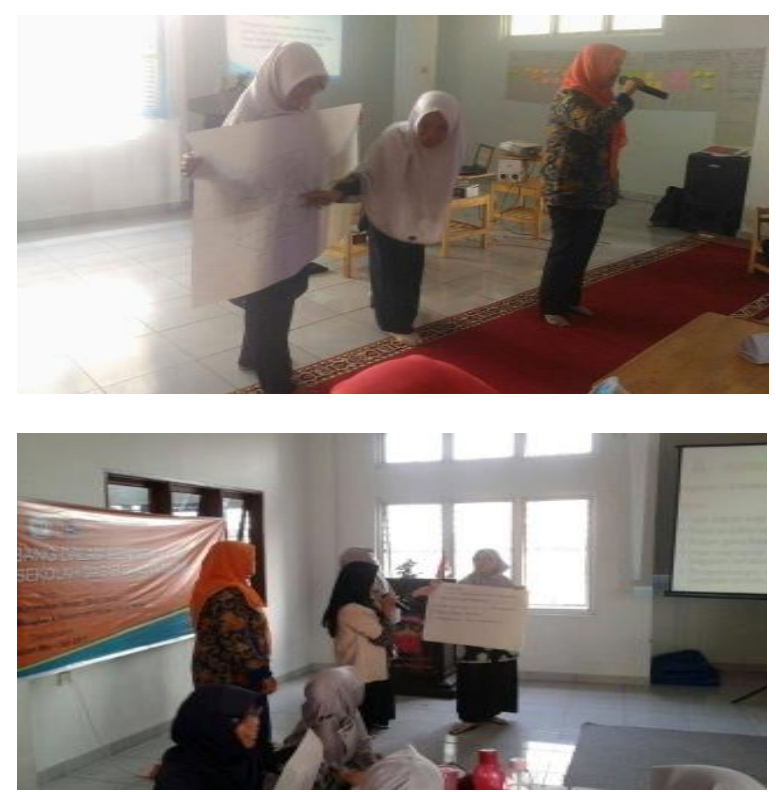

Gambar 4. Kegiatan diskusi setelah materi membaca bersama

Di akhir kegiatan membaca berimbang, peserta diberikan sebuah amplop yang berisi potonganpotongan kertas untuk pemahaman tentang kegiatan membaca berimbang. Kegiatan dikemas dalam bentuk menyusun puzzle mncocokkan apa yang dimaksud dengan membaca bersama, membaca terbimbing dan membaca mandiri terhadap makna masing-masing kegiatan membaca tersebut.

Dalam kegiatan ini peserta diminta untuk merencanakan atau membuat program membaca berimbang di sekolahnya masing-masing. Lembar dengan mengisi lebar kerja yang disediakan. lembar kerja tersebut terdiri dari waktu dalam bentuk hari dan jam, dan frekuensi membaca dalam seminggu. Kegiatan ini bertujuan untuk menindak lanjuti kegiatan pelatihan ini. Hal ini akan dilakukan pada rencana tindak lanjut bulan agustus yang akan datang.

Kegiatan ini guru dikenalkan tentang buku berjenjang yang dimulai dari level A sampai F. Level A adalah level bacaan paling rendah tingkat kesukarannya, sedang kan level $\mathrm{F}$ adalah level yang paling tinggi tingkat kesukarannya untuk kelas rendah. Peserta diajak untuk mengindentifikasi setiap level dan menyampaikan atau mempresentasikan hasil identifikasi ke depan kelas. Fasilitator memberikan penjelasan tentang level level yang ada pada buku berjenjang tersebut. Fasilitator menunjukkan melalui power point secara ringkas isi buku berdasarkan level-levelnya. Karena buku tersebut akan disumbangkan kepada sekolah mitra, fasilitator juga memberikan cara mengelola buku berjenjang tersebut. Dengan cara mengidentifikasi, melabeli, menyampul dan meletakkan ditempat yang sesuai.

Dalam kegiatan ini fasilitator melakukan permainan hompimpa bertujuan untuk mengelola buku berjenjang, dimana makna yangterkandung dalam permainan tersebut harus ada koordinasi atau kerjasama dari berbagai pihak di sekolah untuk bisa mengelola buku dengan baik.

Setelah mendapatkan materi membaca berimbang, pada kegiatan ini guru dipetakan berdasarkan kelas yang diampunya. Kemudian guru mempraktekkan materi membaca bersama dan membaca terbimbing.
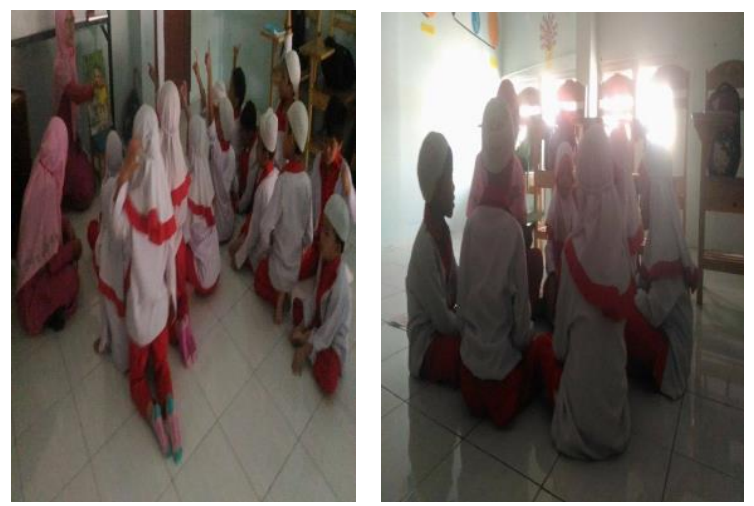

Gambar 5. Praktek pembelajaran membaca bersama dan terbimbing 


\section{KESIMPULAN DAN SARAN}

Big book adalah salah satu media pembelajaran membaca awal yang dapat membantu siswa untuk mengenal huruf, dan latih kemampuan membaca siswa di kelas rendah. Dengan adanya pelatihan pembuatan big book guru dapat dengan mudah mengembangkan bahan ajar membaca di kelas rendah.

Kegiastan membaca berimbang dapat melatih kemampuan membaca sesuai dengan kemampuan siswa. Siswa diajak untuk membaca berdasarkan kemampuan dan level-level buku yang ada. Mulai dari level paling rendah yaitu level A sampai pada level tertinggi yaitu level $\mathrm{F}$.

Dengan adanya buku berjenjang yang disumbangkan ke sekolah, gerakan wajib baca dapat berlangsung dengan baik sehingga minat baca pada siswa di kedua sekolah dapat meningkat.

Kegiatan berikutnya adalah rencana tindak lanjut (RTL), dimana peserta menuyus rencana kegiatan akan diterapkannya di sekolah masing-masing. Pelaksaaan RTL ini akan dimonitoring oleh tim IbM pada bulan berikutnya.

\section{DAFTAR PUSTAKA}

\section{Ester R Manurung}

http://beritasore.com/2014/06/30/kemampuanbaca-anak-sd-di-indonesia-masih-rendah/ diunduh 18 April 2016.

Ratna Wulan

http://ugm.ac.id/id/berita/750-

ratna.wulan:.pelatihan.membaca.dengan.mo del.kognitif.behavioral.tingkatkan.kemampu an.membaca.anak diunduh tanggal 10 April 2016.

Aditya adiaksa

https://www.academia.edu/9147957/MENU

MBUHKAN_MINAT_BACA_UNTUK IN

DONESIA CERDAS diunduh tanggal 18 April 2016.

Mashan Hudi

http://www.realita.co/index.php?news=Mem baca-Berimbang-Latih-Siswa-Pahami-Isi-

Buku-dengan-

Mudah 3b1ca0a43b79bdfd9f9305b8129829 62f0e3c8148b1eb83b56bff4bead38424e diunduh tanggal 18 April 2016.

USAID. Pembelajaran Membaca di Kelas Awal.

USAID. Praktik untuk Sekolah Praktik yang Baik. 